Review

\title{
Cretaceous Ichthyosaurs: Dwindling Diversity, or the Empire Strikes Back?
}

\section{Maria Zammit}

South Australian Museum, North Terrace, Adelaide, South Australia 5000, Australia;

E-Mail: maria.zammit6783@gmail.com

Received: 5 March 2012; in revised form: 19 March 2012 / Accepted: 30 March 2012 /

Published: 12 April 2012

\begin{abstract}
Recent descriptions of new taxa and recognition of survivorship of Jurassic genera across the Jurassic-Cretaceous boundary bring the total number of Cretaceous ichthyosaur genera to eight. Taxa currently known from the Cretaceous include Ophthalmosaurus, Caypullisaurus, Aegirosaurus, Platypterygius, Maiaspondylus, Athabascasaurus, Sveltonectes, and Acamptonectes. This review summarizes the occurrence of all Cretaceous genera. A discussion of morphological diversity demonstrates the different, though overlapping, ecological niches occupied by the different taxa, while the comparison of phylogenetic hypotheses shows the problems inherent in understanding the evolutionary relationships between Cretaceous genera. The Late Jurassic radiation indicated in the competing phylogenetic hypotheses may correlate with the opening of the Atlantic Ocean or additional dispersal routes established by the breakup of Gondwana. Inclusion of the stratigraphically oldest Platypterygius species may aid in resolving these evolutionary relationships.
\end{abstract}

Keywords: Jurassic; Cretaceous; Ichthyosauria; ecological niche; phylogeny

\section{Introduction}

Ichthyosaur fossils have been found on all continents [1], and range in age from Late Triassic-early Late Cretaceous [2]. During this time, ichthyosaur diversity was thought to be greatest in the Middle Triassic, lower in the Jurassic with a peak in the Liassic, but dwindled to a single genus, Platypterygius, in the Cretaceous [3]. Low diversity in the Cretaceous was also noted by Mazin et al. [4], though Bardet $[5,6]$ thought that additional genera were present. 
Recent finds have shown that Platypterygius was not the only Cretaceous genus. Five genera are now known to occur only in the Cretaceous-Platypterygius [2,7], Maiaspondylus [8], Athabascasaurus [9], Sveltonectes [10], and Acamptonectes [11]. In addition, several Jurassic genera have been shown to extend into the Cretaceous, contradicting the end-Jurassic extinction hypothesis for ichthyosaurs and further increasing ichthyosaur diversity [12]. Previous reviews on Cretaceous ichthyosaur occurrences (e.g., [6,13]) predate the recent interest generated by these new discoveries. As a result, a review of Cretaceous ichthyosaur occurrences is timely. Here, this review is combined with a discussion of ecological niches as determined by tooth morphology, and the current phylogenetic theories (and thus, evolutionary hypotheses) for the last known members of the Ichthyosauria.

\section{Results and Discussion}

\subsection{Ichthyosaur Genera in the Cretaceous}

\subsubsection{Platypterygius}

The genus Platypterygius was the first (and until recently, sole) ichthyosaur known from the Cretaceous, and is a geographically widespread and geologically long-lived genus. Its status as a wastebasket taxon has been noted by many authors [11]. Previously, it was thought that all members of this group may eventually be synonymized into fewer species [14], or that they may belong to a single supraspecific taxon [5] - this is in contrast to the more recent theory that the genus may eventually be split into additional genera, supported by the morphological disparity noted by Fischer [15]. Indeed, the genus as it currently stands may be polyphyletic [9-11]. Pending further revision, eight species of Platypterygius are discussed here: five previously recognized by McGowan and Motani [2], Platypterygius hauthali, Platypterygius platydactylus, Platypterygius australis, Platypterygius americanus, and Platypterygius campylodon; Platypterygius hercynicus, synonymized with P. campylodon by McGowan and Motani [2], but considered a separate valid species by Kolb and Sander [16]; an additional species from South America not considered in McGowan and Motani's [2] extensive review, Platypterygius sachicarum; and Platypterygius ochevi, a species erected subsequent to McGowan and Motani's [2] review by Arkhangelsky et al. [17].

Platypterygius hauthali-Originally described as Myobradypterygius hauthali, von Huene [18] erected this South American ichthyosaur on forelimb material from the Barremian [19] of Argentina (Figure 1)-McGowan [13] referred the specimen to the genus Platypterygius. McGowan and Motani [2] retained the species, but thought it might prove synonymous with the contemporaneous Platypterygius platydactylus. However, Fernández and Aguirre-Urreta [19] undertook a revision of the holotype material, and considered it a valid species based on its carpal pattern. Hauterivian-Barremian occurrences of this species have been reported in southern-most Chile [20,21], but descriptions are currently limited to a single forefin considered Platypterygius sp [22]. Description of this relatively complete material may aid in distinguishing the two contemporaneous South American species, the holotypes of which do not share comparable elements.

Platypterygius platydactylus_-Platypterygius platydactylus was first described by Broili [7] from the Aptian of Germany (Figure 1), and is the type species for the genus Platypterygius. Unfortunately, 
the holotype was destroyed during World War II [2], and additional material for this species has not yet been reported.

Platypterygius australis-Australia's species of Platypterygius, Platypterygius australis, include the best preserved, most abundant, and most complete remains of this genus [23]. Originally described in the nineteenth century from the Albian of Queensland [24,25], the erection of this species on non-diagnostic material has led to confusion surrounding the taxonomic identity of Australian specimens (as summarized — and resolved — by Zammit [26])—Platypterygius marathonensis [27] and Platypterygius longmani [28] have been synonymized with this taxon [2,13,29]. Remains attributable to this species have also been reported from the Aptian-Albian of South Australia and the Northern Territory [29] (Figure 1).

Figure 1. Cretaceous ichthyosaur occurrences for the (A) Berriasian-Valanginian; (B) Barremian-Hauterivian; (C) Aptian; (D) Albian; and (E) Cenomanian. Base maps from Smith et al. [30]. Symbols: Acamptonectes densus, grey star; Aegirosaurus leptospondylus, grey triangle; Athabascasaurus bitumineus, grey diamond; Caypullisaurus bonapartei, grey circle; Maiaspondylus lindoei, grey 'plus' symbol; Ophthalmosaurus sp., grey square; Platypterygius americanus, black 'plus' symbol; Platypterygius australis, black diamond; Platypterygius campylodon, black asterisk; Platypterygius hauthali, black triangle; Platypterygius hercynicus, black circle; Platypterygius ochevi, black square; Platypterygius platydactylus, black star; Platypterygius sachicarum, black hexagon.
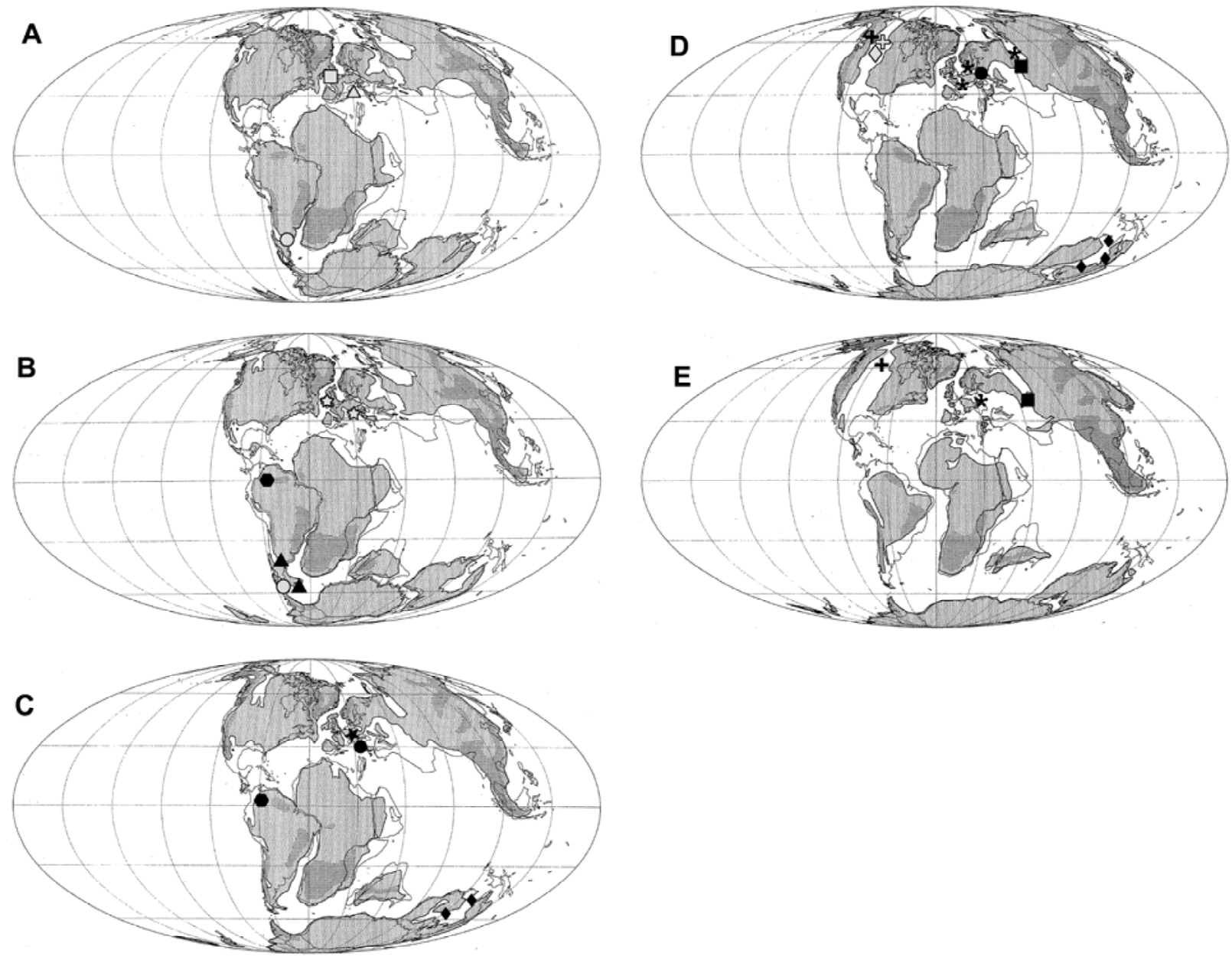
Platypterygius campylodon-Originally referred to Ichthyosaurus, Platypterygius campylodon was first described in 1846 from Cambridge, UK [31]. The brief type description was followed by a slightly longer report later in the same year [32]. This species is now known from the Albian-Cenomanian of England [33], France [6], and Russia [2,34,35], and the Cenomanian of Germany [36] (Figure 1). However, the taxonomy of several Russian species is uncertain-Storrs et al. [35] provisionally retained Platypterygius bedengensis, Platypterygius birjukovi, Platypterygius bannovkensis, and Platypterygius kiprijanoffi, while McGowan and Motani [2] considered all four taxon nomen dubium and synonymized the latter two taxa with P. campylodon. The revision of McGowan and Motani [2] is followed here as (a) Storrs et al. [35] were uncertain regarding the validity of $P$. bannovkensis, $P$. bedengensis, and P. birjukovi holotypes for taxonomic diagnosis, and (b) McGowan and Motani [2] demonstrated that the characteristic features of $P$. kiprijanoffi are not diagnostic.

Platypterygius americanus-Platypterygius americanus was first described from the upper Albian [23] of Wyoming [37] — originally described as a new genus, Myopterygius, it was later referred to Platypterygius [13]. It also occurs in the Lower Cenomanian of Wyoming [23,38] (Figure 1).

Platypterygius hercynicus - Though Platypterygius hercynicus was originally described in 1946 [39], it was synonymized with $P$. platydactylus [2] before being resurrected by Kolb and Sander [16]. Resurrection of the species was further supported by Fischer [15], based on the cranial characters of a referred specimen. The species occurs in the Aptian and upper Albian sediments of Lower Saxony, Germany, and north-western France, respectively [15] (Figure 1).

Platypterygius sachicarum-Platypterygius sachicarum is the second species of Platypterygius known from South America. The holotype, consisting of a nearly complete skull, was identified as being derived from the Barremian-Aptian Paja Formation of Colombo [40] (Figure 1). Cranial features suggested a closer affinity with the North American species than the Australian or Eurasian forms [40], but this is yet to be tested in a phylogenetic analysis. Currently, the holotypes of the two South American Platypterygius do not share comparable elements, and thus, may eventually be synonymized-however, Fernández and Aguirre-Urreta [19] point out that there is a conspicuous difference in size.

Platypterygius ochevi-Described by Arkhangelsky et al. [17], Platypterygius ochevi was erected on features of the forelimb, specifically the large size of the humeral facet for the extra zeugopodial element anterior to the radius-however, the taxonomic utility of this character requires assessment (an opinion shared by Fischer et al. [11]). It is provisionally retained here pending re-examination of the material. The remains of this species of Platypterygius occur in the Albian-Cenomanian strata of the Voronezh Region, Russia [17] (Figure 1).

Additional Platypterygius remains-Several other occurrences attributed to Platypterygius also need to be considered. This includes Lydekker's [41] Ichthyosaurus indicus, which was erected on fifteen associated vertebrae from the Cretaceous of India. This material was considered indeterminate by McGowan and Motani [2]—despite this, Underwood et al. [42] tentatively referred teeth to Lydekker's [41] species, placing the material in Platypterygius indicus. The teeth were placed in this genus based on similarity to Platypterygius, and the proximity to Lydekker's [41] locality. However, the tooth form in other Cretaceous ichthyosaurs, such as Brachypterygius, is similar to Platypterygius [8] - thus, a more detailed comparison is required to conclusively show the teeth can be referred to Platypterygius. 
Specimens from Italy [43], New Zealand [44], and Bavaria [45] have also been referred to Platypterygius. Bardet et al. [45] considered the robustness of the Bavarian remains (and the inferred large size) and tooth morphology consistent with Platypterygius sp. However, the fragmentary specimens from Italy and New Zealand were assigned to Platypterygius in part because no other Cretaceous genus was known at the time of discovery. Further examination may provide additional support for referral to this genus, particularly for the largest, well-preserved rostral fragment figured by Sirotti and Papazzoni [43].

Each species of Platypterygius appears to be endemic to a given region (Figure 1), though this may in part be due to geographic criteria being used in taxonomic assignment, e.g., [44]. However, Platypterygius remains have been described from both North America and Australia that appear inconsistent with the endemic species. The specimens described by Maxwell and Caldwell [46] and Adams and Fiorillo [47] appear to show more similarity with the European or Australian forms of this genus-however, while the forefin figured by Adams and Fiorillo [47] is consistent with the forelimbs of $P$. hercynicus and $P$. australis, the atlas-axis complex lacks the suture at the base of the neural canal exhibited by these two species [48,49]. Choo [50] described a fragmentary humerus that was more comparable with European rather than Australian or North American forms. Due to the incomplete nature of the material, the affinities of this humerus are uncertain-however, if this interpretation is upheld, the potential implication of this find is the possibility of two ichthyosaur dispersal events into Australia, as mentioned by Kear [51].

\subsubsection{Maiaspondylus}

Maiaspondylus consists of a single species, Maiaspondylus lindoei, recovered from the Albian of the Northwest Territories, Canada [8] (Figure 1). The holotype of M. lindoei was found associated with ichthyosaur remains referred to Platypterygius [46], indicating that the two genera occurred together.

\subsubsection{Athabascasaurus}

Athabascasaurus consists of a single species, Athabascasaurus bitumineus, described from the earliest Albian of Alberta, Canada [9] (Figure 1). The holotype consists of a nearly complete skull and partial postcranial skeleton that was collected in 2000 [9]. Platypterygius remains have been reported from the same formation containing Athabascasaurus [9].

\subsubsection{Sveltonectes}

Described from the upper Barremian of western Russia (Figure 1), the genus Sveltonectes contains a single species, Sveltonectes insolitus, erected on a nearly complete skeleton [10]. As a result, the authors have been able to identify many unique features, some of which relate to diet and swimming style that were also used to establish the generic name (see Etymology of Fischer et al. [10]).

\subsubsection{Acamptonectes}

The most recently described Cretaceous genus, Acamptonectes, is monotypic, only containing the species Acamptonectes densus. It occurs in the basal Hauterivian-upper Hauterivian of north 
Yorkshire, UK, and Lower Saxony, Germany [11] (Figure 1). Specimens attributable to the genus have also been identified from the Albian-Cenomanian of Cambridge, UK, but show features that differ from the already described species [11]. The preserved section of the snout is slender, exhibiting one of the lowest snout depth ratios in all known ophthalmosaurid ichthyosaurs, though the relative length of the rostrum is unknown [11]. Together with the tooth morphology described by Fischer et al. [11], this may indicate a different diet and thus lifestyle to previously known Cretaceous ichthyosaurs.

\subsubsection{Ichthyosaurs Crossing the Jurassic—Cretaceous Boundary}

Ophthalmosaurus -Ophthalmosaurus is a well-known Jurassic ichthyosaur. The extension of this genus into the Cretaceous has been suggested by several authors [2,52,53], but a recent study [11] considers these reports to be ambiguous as the elements may belong to other genera now known from the Cretaceous. However, the same study refers a basioccipital and humerus from the Berriasian of the UK (Figure 1) to cf. Ophthalmosaurus, indicating survival across the Jurassic-Cretaceous boundary.

Caypullisaurus - Previously thought to be limited to the Upper Jurassic [1], the monotypic genus Caypullisaurus has since been shown to extend into the Berriasian (Lower Cretaceous) of Argentina [54] (in Reference [19]) (Figure 1). Additional material that may be attributed to Caypullisaurus has been recovered from the Hauterivian-Barremian of Chilean Patagonia, and occurs with $P$. hauthali $[20,21]$.

Aegirosaurus - the anterior part of a rostrum is the only record of Aegirosaurus from the Cretaceous. Found in late Valanginian strata of southeastern France (Figure 1), the snout was referred to this genus based on four characters: anterior-posterior order in which the cranial bones emerged; slenderness of the snout; tooth morphology; and tooth density [55]. This species was previously only known from the upper Jurassic [2]. Like P. platydactylus, holotype material was destroyed during World War II (though syntype material, thin sections of the teeth, survived, [56]), but comparable material was referred to the genus at the beginning of the 21st Century [57].

Additional Genera-In addition to Ophthalmosaurus, Caypullisaurus, and Aegirosaurus, Brachypterygius may also have crossed the Jurassic-Cretaceous boundary. Ensom et al. [58] redescribed and dated an indeterminate ichthyosaur specimen that had affinities with Brachypterygius. Pending comparison with additional Cretaceous genera (such as Maiaspondylus), this material indicates that another Jurassic ichthyosaur may have survived into the Cretaceous.

\subsection{Diversity and Evolution of Cretaceous Ichthyosaurs}

The review of Cretaceous ichthyosaur occurrences demonstrates that five genera are currently known only from the Cretaceous, while at least three (and possibly four) additional Jurassic genera cross the Jurassic-Cretaceous boundary. The majority of this increased diversity has been recognized only recently (e.g., Maxwell and Caldwell [8] (p. 1043) state that "All Cretaceous ichthyosaurs are referred to a single genus, Platypterygius Huene, 1922”), and dispute the hypothesis of low taxonomic diversity within the Ichthyosauria prior to their extinction, though Cenomanian occurrences remain extremely rare. Further, some faunas include ichthyosaur fossils referred to two genera (e.g., Platypterygius and Maiaspondylus, [8]) — this may have been possible through different adaptations (i.e., morphological diversity) that allowed the ichthyosaurs to exploit different ecological niches. 
One feature that has been linked to diet, and thus ecological niche, is tooth form. Massare [59] proposed seven predatory guilds (condensed to six in Massare [60]) based on tooth morphology and tooth wear in Jurassic marine reptiles. However, placing some Cretaceous ichthyosaurs within this framework is difficult when (a) their teeth exhibit characters that are present in several different guilds (e.g., [55]), or (b) when inferences of diet cannot be supported by stomach contents [10]. Despite these concerns, diet has been inferred for Cretaceous ichthyosaurs with some success. Fischer et al. [10] considered the slender, pointed teeth of Sveltonectes intermediate between the 'pierce I' and 'pierce II/generalist' guilds of Massare [59], thus inferring a diet of soft to very soft prey or small bony prey. Aegirosaurus exhibits tooth morphologies that are present in both the 'pierce I' and 'pierce II/generalist' guilds of Massare [59], but was most consistent with the 'pierce II/generalist' guild [55], indicating a diet of fleshy prey that lacked a hard exterior. As pointed out by Fischer et al. [55], this guild was previously restricted to some pliosauroids, plesiosauroids, and thalattosuchians, and Aegirosaurus was included within this guild on the provision that it likely fed on smaller prey than the other predators. The slender tooth crown with longitudinal ridges observed in Acamptonectes [11] and Athabascasaurus [9] may also correspond to the 'pierce II/generalist' guild of Massare [59], though the ridges in the latter are less prominent. The four ichthyosaurs considered probably impaled prey rather than grasping it, or, for Sveltonectes, used the teeth as a sieve [59].

Though previously considered edentulous [61], teeth are not firmly attached in Ophthalmosaurus and generally lost [2]. This genus has been described as having small, conical teeth [55,62] with a pointed apex bearing fine longitudinal ridges [63]. The size of the teeth suggests inclusion within Massare's [59] 'smash' guild, while the crown morphology is consistent with the 'general' guild. This indicates a diet consisting of fleshy prey that may have contained some internal hard parts, but the method of prey capture may have been either grasping or impaling [60]. Similarly, Caypullisaurus is currently considered edentulous [64], though a single specimen figured by Fernández [65] has teeth in the anterior section of the jaws. The preserved teeth are described as having a similar shape to Ophthalmosaurus, and bear striations on the crown [65]. Apices of the teeth are not preserved. Thus, tooth morphology tentatively indicates a similar method of prey capture and diet to Ophthalmosaurus - however, the edentulous nature of most Caypullisaurus individuals suggests either ontogenetic variation in diet [65], or post-mortem loss of teeth resulting from weak attachment to the jaws (as in Ophthalmosaurus).

Platypterygius (and Maiaspondylus, which as a similar tooth morphology but more weakly developed enamel ornamentation, [8]) is more complex. The large robust teeth of $P$. campylodon were figured as an example of the 'smash' guild that fed on soft prey with some internal hard parts [59,60], and the tooth form described by Fischer [15] for P. hercynicus also corresponds to the morphology of this guild. However, as discussed by Fischer et al. [10], stomach contents of $P$. australis, which shares the 'smash' guild tooth morphology [66], indicated a less restricted diet that included scavenging and opportunistic feeding on vertebrates [67]. In addition, Kear and Barrett [68] hypothesized that the robust teeth of $P$. campylodon may have been an adaptation to feed on hard-shelled invertebrates, which would place this species within the 'crunch' guild of Massare [60]. Placing the genus Platypterygius in the 'crunch' guild would also be more consistent with the stomach contents described from $P$. australis. However, the slender, moderately long teeth described for $P$. americanus by Nace [38] are difficult to place in Massare's [59] guilds, but may correspond to the 'smash' or 
'general' guilds. This suggests that either prey preference varies between species of Platypterygius, or the teeth of Platypterygius can be adapted to several different potential diets and prey handling strategies. The tooth form in Maiaspondylus is similar to Platypterygius [8], and is thus consistent with the 'smash' guild of Massare [60] — however, stomach contents, if discovered, may indicate a less restricted diet, as for $P$. australis. Regardless of the prey consumed, all but one of the predator guilds considered for Platypterygius and Maiaspondylus use the same handling technique-grasping prey rather than impaling it (the general guild is the only one considered that was thought to incorporate impaling rather than grasping, Massare [60]). Thus, while there is some dietary overlap between Cretaceous ichthyosaurs, the differences in tooth morphology would also have likely allowed exploitation of different resources.

While the morphological diversity present in Cretaceous ichthyosaurs can no longer be denied, how this diversity evolved has not yet been investigated. Relationships between Cretaceous ichthyosaurs have only recently come under scrutiny [9-11]. Results vary between analyses, though the minor differences exhibited by Fischer et al. [10] and Fischer et al. [11] possibly result from the inclusion of additional taxa (i.e., Ophthalmosaurus natans and Acamptonectes). The only consistent result found in these analyses is that the genera Ophthalmosaurus and Platypterygius as currently defined are polyphyletic, and thus a reanalysis of these two genera is warranted [9,11]-however, the additional taxa included within the two genera varies (Figure 2). In Fischer et al. [11], the two Ophthalmosaurus species were separated by Acamptonectes, and were located at the crown of one clade. The relationship between Ophthalmosaurus natans and Ophthalmosaurus icenicus was more complicated in Druckenmiller and Maxwell [9]—O. icenicus and Aegirosaurus were recovered as sister taxa, and separated $O$. natans from the rest of the Ophthalmosauridae. The difference here may in part result from the inclusion of the new taxon Acamptonectes. Druckenmiller and Maxwell [9] found a polytomy containing a Maiaspondylus-P. americanus sister-group, P. australis, P. hercynicus, P. americanus, Caypullisaurus, and Arthropterygius. In contrast, Fischer et al. [11] recovered a four-taxon clade where Caypullisaurus separated a P. australis-Athabascasaurus sister-relationship and $P$. hercynicus. This could be related to the exclusion of P. platydactylus in the study of Fischer et al. [11].

Tree topology varies greatly between the analyses (Figure 2). Druckenmiller and Maxwell [9] recover a 'classic' branching pattern with a crownward polytomy. Fischer et al. [11], on the other hand, splits the Ophthalmosauridae into two major radiations, the Ophthalmosaurinae and the Platypterygiinae, the latter containing two branches. Both phylogenetic hypotheses indicate a ghost lineage for Platypterygius extending into the Late Jurassic - either through the origin of $P$. hercynicus in the Kimmeridgian prior to the first appearance of Caypullisaurus [11], or P. australis, $P$. platydactylus, and $P$. hercynicus occurring with the first appearance of Caypullisaurus in the Tithonian [9]. Inclusion of the oldest known Platypterygius, P. hauthali and P. sachicarum, may further change these results. The positions of several taxa also vary greatly between the phylogenetic analyses. Several taxa are recovered in both stem- and crown-ward positions (e.g., Athabascasaurus, Aegirosaurus, and Arthropterygius). Different taxa also separate species of the problematic genus Platypterygius-Athabascasaurus and Caypullisaurus [11], or Maiaspondylus, Arthropterygius, and Caypullisaurus [9]. 
Figure 2. Stratigraphy-related phylogenetic trees. (A) modified from Fischer et al. [11]; (B) modified from Druckenmiller and Maxwell [9]. Ichthyosaurus communis and Ophthalmosaurus icenicus now extend into the Pliensbachian [69] and Tithonian [62], respectively. Black bars indicate species occurrence within an epoch. White bars indicate a species is not known from this epoch, but occurs in surrounding epochs. Abbreviations: Aal, Aalenian; Ba, Bajocian; Bar, Barremian; Ber, Berriasian; Bt, Bathonian; Ca, Callovian; Cen, Cenomanian; H, Hettangian; Ha, Hauterivian; Kim, Kimmeridgian; Nor, Norian; Oxf, Oxfordian; Pli, Pliensbachian; Rh, Rhaetian; Sin, Sinemurian; Tit, Tithonian; Toar, Toarcian; Val, Valanginian.

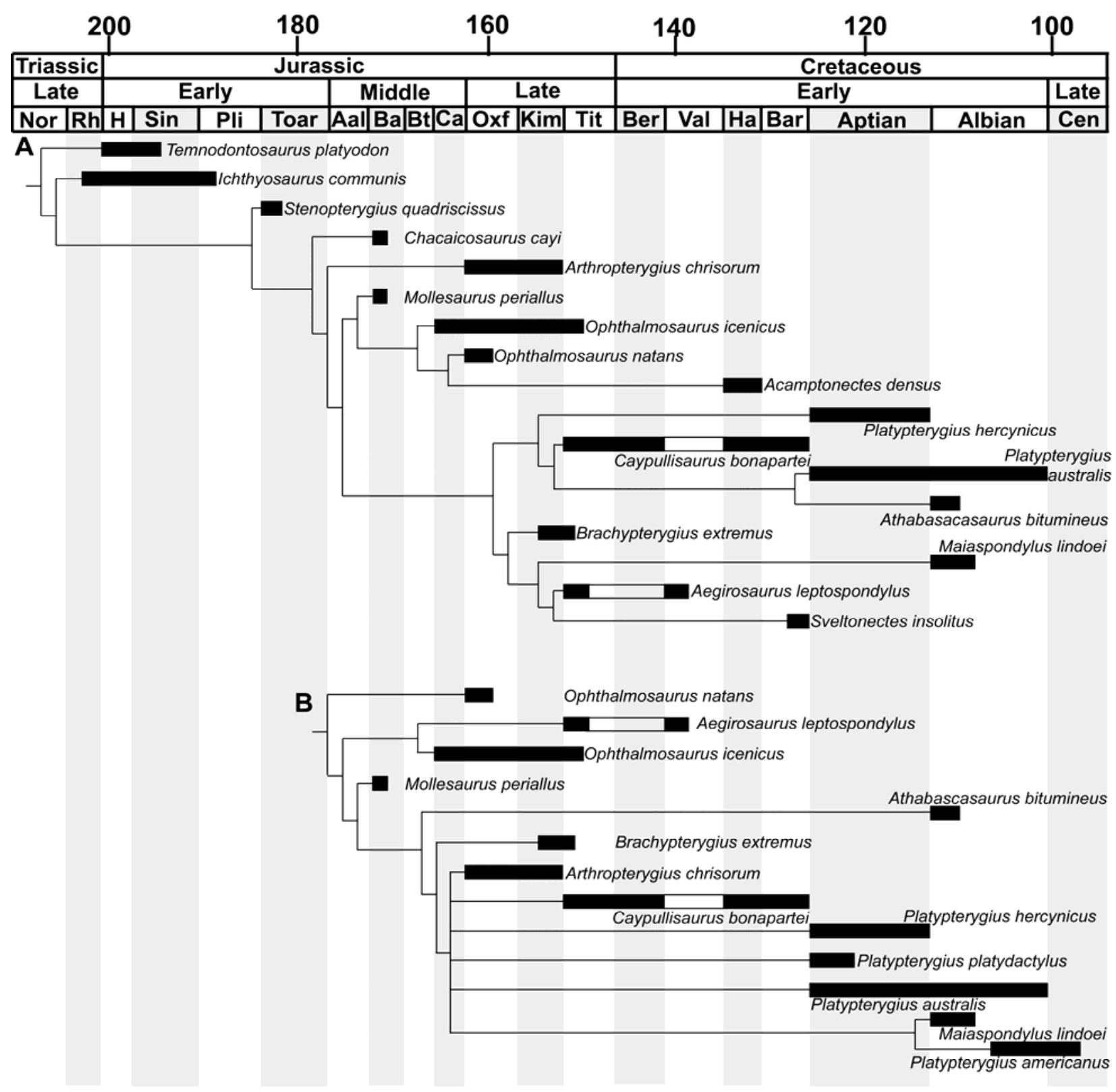

So, what do the divergent phylogenetic hypotheses tell us about the origins and evolution of Cretaceous ichthyosaurs? The radiation of Platypterygius [9] or the emergence of the Platypterygiinae [11] during the Late Jurassic could coincide with the opening of the Atlantic Ocean [70], or new dispersal routes through the breakup of Gondwana [71]. With the exception of the Maiaspondylus-P. americanus sister 
relationship recovered by Druckenmiller and Maxwell [9], the phylogenetic positions of Cretaceous genera do not appear to correlate with stratigraphic position or proximity-for example, $P$. australis and Athabascasaurus were recovered as sister-taxa [11], yet are found in strata of the same age from different continents (Figure 1). Further, sister relationships were not recovered between Platypterygius species collected from similar localities (i.e., P. hercynicus and P. platydactylus, Druckenmiller and Maxwell [9]), suggesting the absence of phylogeographic structuring (i.e., widespread panmixia), and possibly dispersal between non-adjacent regions - this is perhaps unsurprising given that Platypterygius material inconsistent with the endemic species (i.e., most likely belonging to a non-endemic species) has been found in North America [46]. To more fully understand the origins and evolution of Cretaceous ichthyosaurs, the phylogenetic position of some of the stratigraphically oldest specimens (e.g., $P$. hauthali and P. sachicarum, the former of which contains a newly referred, complete specimen, Pardo Perez et al. [21]) needs to be investigated.

\section{Conclusions}

A total of eight genera are known from the Cretaceous-Platypterygius, Maiaspondylus, Athabascasaurus, Sveltonectes, and Acamptonectes are found only in the Cretaceous, while Ophthalmosaurus, Aegirosaurus, and Caypullisaurus cross the Jurassic-Cretaceous boundary. The different genera likely occupied different, though overlapping, ecological niches. This is supported by different tooth morphologies, indicating different diets, and sympatry of two genera (e.g., Caypullisaurus and Platypterygius, and Maiaspondylus and Platypterygius). Phylogenetic relationships between Cretaceous ichthyosaurs remain problematic, with tree topology varying between analyses. As a result, little can be stated with certainty regarding the radiation and dispersal of these ichthyosaurs, though the emergence of some forms in the Late Jurassic may have coincided with the opening of the Atlantic Ocean or the breakup of Gondwana. Inclusion of the stratigraphically oldest species (e.g., Platypterygius hauthali and Platypterygius sachicarum) may shed additional light on the evolution of the group.

\section{Acknowledgments}

Many thanks to authors who provided copies of their journal articles that would otherwise have been difficult to obtain: Nathalie Bardet, Maxim Arkhangelsky, Cajus Diedrich, to name but a few. Use of the Barr Smith Library (University of Adelaide) in locating references is acknowledged. Thanks also to Ben Kear and Nicolas Rawlence for their comments on the manuscript.

\section{References}

1. Maisch, M.W.; Matzke, A.T. The Ichthyosauria. Stuttg. Beitr. Naturkunde Ser. B (Geolog. Paläontol.) 2000, 298, 1-159, in German.

2. McGowan, C.; Motani, R. Ichthyopterygia. Handbook of Paleoherpetology; Sues, H.D., Ed.; Verlag Dr. Friedrich Pfeil: Munich, Germany, 2003; Volume 8, p. 175.

3. Sander, P.M. Ichthyosauria: Their diversity, distribution, and phylogeny. Paläontol. Z. 2000, 74, $1-35$. 
4. Mazin, J.M.; Bardet, N.; Godefroit, P. The European Ichthyopterygia: A re-assessment. J. Vertebr.Paleontol. 1994, 14, 36-37.

5. Bardet, N. Dental cross-sections in Cretaceous Ichthyopterygia: Systematic implications. Geobios-LYON 1990, 23, 169-172.

6. Bardet, N. Stratigraphic evidence for the extinction of ichthyosaurs. Terra Nova 1992, 4, 649-656.

7. Broili, F. Ein neuer Ichthyosaurus aus der norddeutschen Kreide. Palaeontogr. 1907, 54, 139-152, in German.

8. Maxwell, E.E.; Caldwell, M.W. A new genus of ichthyosaur from the Lower Cretaceous of western Canada. Palaeontology 2006, 49, 1043-1052.

9. Druckenmiller, P.S.; Maxwell, E.E. A new Lower Cretaceous (lower Albian) ichthyosaur genus from the Clearwater Formation, Alberta, Canada. Can. J. Earth Sci. 2010, 47, 1037-1053.

10. Fischer, V.; Masure, E.; Arkhangelsky, M.S.; Godefroit, P. A new Barremian (Early Cretaceous) ichthyosaur from western Russia. J. Vertebr. Paleontol. 2011, 31, 1010-1025.

11. Fischer, V.; Maisch, M.W.; Naisch, D.; Kosma, R.; Liston, J.; Joger, U.; Krüger, F.J.; Pardo Pérez, J.; Tainsh, J.; Appleby, R.M. New ophthalmosaurid ichthyosaurs from the European Lower Cretaceous demonstrate extensive ichthyosaur survival across the Jurassic-Cretaceous boundary. PloS ONE 2012, 7, 1-23.

12. Fischer, V. New ophthalmosaurids from Europe and Russia broaden the biodiversity of Early Cretaceous ichthyosaurs. J. Vertebr. Paleontol. Suppl. 2011, 31, 110.

13. McGowan, C. The systematics of Cretaceous ichthyosaurs with particular reference to the material from North America. Contrib. Geol. Univ. Wyo. 1972, 11, 9-29.

14. McGowan, C. Dinosaurs, Spitfires, and Seadragons, 1st ed.; Harvard University Press: Cambridge, MA, USA, 1991; p. 365.

15. Fischer, V. New data on the ichthyosaur Platypterygius hercynicus and its implications for the validity of the genus. Acta Palaeontol. Pol. 2012, 57, 123-134.

16. Kolb, C.; Sander, P.M. Redescription of the ichthyosaur Platypterygius hercynicus (Kuhn 1946) from the Lower Cretaceous of Salzgitter (Lower Saxony, Germany). Palaeontogr. Abt. A. 2009, 288, 151-192.

17. Arkhangelsky, M.S.; Averianov, A.O.; Pervushov, E.M.; Tarnikow, V.Y.; Zozyrev, N.Y. On ichthyosaur remains from the Cretaceous of the Voronezh Region. Palaeontol. J.2008, 42, 287-291.

18. Von Huene, F. Beitrag zur Kenntnis mariner mesozoischer Wirbeltiere in Argentina. Zent. Mineral. Geolog. Paläontol. B 1927, 1927, 22-29; in German.

19. Fernández, M.; Aguirre-Urreta, M.B. Revision of Platypterygius hauthali von Huene, 1927 (Ichthyosauria: Ophthalmosauridae) from the Early Cretaceous of Patagonia, Argentina. J. Vertebr. Paleontol. 2005, 25, 583-587.

20. Pardo Pérez, J.; Frey, E.; Stinnesbeck, W.; Salazar, C.; Leppe, M. Life and death on the Torres del Pain ichthyosaurs, southern Chile. In Proceedings of 7th Annual Meeting of the European Association of Vertebrate Palaeontologists, Berlin, Germany, 20-24 July 2009; p. 55.

21. Pardo Pérez, J.M.; Frey, E.; Stinnesbeck, W.; Rivas, L. Early Cretaceous ichthyosaurs from the Tyndall Glacier in Torres Del Paine National Park, southernmost Chile. J. Vertebr. Paleontol. Suppl. 2011, 31, 171. 
22. Pardo-Pérez, J.; Frey, E.; Stinnesbeck, W.; Fernánez, M.S.; Rivas, L.; Salazar, C.; Leppe, M. An ichthyosaurian forefin from the Lower Cretaceous Zapata Formation of southern Chile: Implicaitons for morphological variability within Platypterygius. Palaeobio. Palaeoenv. 2012, in submission.

23. Maxwell, E.E.; Kear, B.P. Postcranial anatomy of Platypterygius americanus (Reptilia: Ichthyosauria) from the Cretaceous of Wyoming. J. Vertebr. Paleontol. 2010, 30, 1059-1068.

24. McCoy, F. On the occurrence of Ichthyosaurus and Plesiosaurus in Australia. J. Nat. Hist. Third Ser. 1867, 19, 355-356.

25. McCoy, F. On the discovery of Enaliosauria and other Cretaceous fossils in Australia. Trans. Proc. Rol. Soc. Vic. 1867, 8, 41-42.

26. Zammit, M. A review of Australasian ichthyosaurs. Alcheringa 2010, 34, 281-292.

27. Etheridge, R. On additional evidence of the genus Ichthyosaurus in the Mesozoic rocks ("Rolling Downs Formation”) of north-eastern Australia. P. Linn. Soc. N. S. W.1888, 2, 405-409.

28. Wade, M. A review of the Australian Cretaceous longipinnate ichthyosaur Platypterygius (Ichthyosauria, Ichthyopterygia). Mem. Qld. Mus. 1990, 28, 115-137.

29. Kear, B.P. Cretaceous marine reptiles of Australia: A review of taxonomy and distribution. Cretaceous Res. 2003, 24, 277-303.

30. Smith, A.G.; Smith, D.G.; Funnell, B.M. Atlas of Mesozoic and Cenozoic Coastlines; Cambridge University Press: Cambridge, UK, 1994; p. 99.

31. Carter, J. Notice of the jaws of an Ichthyosaurus from the chalk in the neighbourhood of Cambridge. Rep. Br. Assoc. Advanc. Sci. 1846, 1845, 60.

32. Carter, J. On the occurrence of a new species of Ichthyosaurus in the chalk. Lond. Geol. J. Rec. Discov. Br. Foreign Paleontol. 1846, 1, 7-9.

33. Owen, R. A monograph on the fossil Reptilia of the Cretaceous formations. Palaeontogr. Soc. Monogr. 1851, 5, 1-118.

34. Kiprijanoff, W. Studien über die fossilen Reptilien Russlands. Theil 1. Gattung Ichthyosaurus Konig aus dem Sewerischen Sandstein oder Kreide-Gruppe. Mém. Acad. Imp. Sci. St.-Pétersbg. 7e Sér. 1881, 28, 1-103, in German.

35. Storrs, G.W.; Arkhangelsky, M.S.; Efimov, V.M. Mesozoic marine reptiles of Russia and other former Soviet Republics. In The Age of Dinosaurs in Russia and Mongolia; Benton, M.J., Shishkin, M.A., Unwin, D.M., Kurochkin, E.N. Eds; Cambridge University Press: Cambridge, UK, 2000; pp 187-210.

36. Diedrich, C. New ichthyosaur remains of Platypterygius cf. campylodon (Carter 1846) (Ichthyopterygia, Reptilia) from the Cenomanian of NW Germany. Munstersche Forschungen Geol. Palaontol. 2002, 93, 97-108.

37. Nace, R.L. A new ichthyosaur from the Upper Cretaceous Mowry formation of Wyoming. Am. J. Sci. 1939, 237, 673-686.

38. Nace, R.L. A new ichthyosaur from the Late Cretaceous, Northeast Wyoming. Am. J. Sci. 1941, 239, 908-914.

39. Kuhn, O. Ein Skelett von Ichthyosaurus (Platypterygius) hercynicus n. sp. aus dem Aptium von Gitter. Ber. Naturforschenden Ges. Bamb. 1946, 29, 69-82; in German. 
40. Páramo, M.E. Platypterygius sachicarum (Reptilia, Ichthyosauria) neuva especie del Cretacico de Colombia. Rev. Ingeominas 1997, 6, 1-12, in Spanish.

41. Lydekker, R. Indian Pre-Tertiary vertebrate fossil Reptilia and Batrachia. Mem. Geolog. Surv. India 1879, 1, 1-36.

42. Underwood, C.J.; Goswami, A.; Prasad, G.V.R.; Verma, O.; Flyn, J.J. Marine vertebrates from the 'middle' Cretaceous (early Cenomanian) of south India. J. Vertebr. Paleontol. 2011, 31, 539-552.

43. Sirotti, A.; Papazzoni, C. On the Cretaceous ichthyosaur remains from the Northern Apennines (Italy). Boll. Soci. Paleontol. Ital. 2002, 41, 237-248.

44. Sachs, S.; Grant-Mackie, J.A. An ichthyosaur fragment from the Cretaceous of Northland, New Zealand. J. Royal Soc. New Zealand 2003, 33, 307-314.

45. Bardet, N.; Wellnhofer, P.; Herm, D. Discovery of ichthyosaur remains (Reptilia) in the Upper Cenomanian of Bavaria. Mitt. Bayer. Staatssamml. Paläontol. Hist. Geol.1994, 34, 213-220.

46. Maxwell, E.E.; Caldwell, M.W. Evidence for a second species of the ichthyosaur Platypterygius in North America: A new record from the Loon River Formation (Lower Cretaceous) of Northwestern Canada. Can. J. Earth Sci. 2006, 43, 1291-1295.

47. Adams, T.L.; Fiorillo, A. Platypterygius Huene, 1922 (Ichthyosauria, Ophthalmosauridae) from the Late Cretaceous of Texas, USA. Palaeontol. Electron. 2010, 14, 12.

48. Maxwell, E.E.; Kear, B.P. Postcranial anatomy of Platypterygius americanus (Reptilia: Ichthyosauria) from the Cretaceous of Wyoming. J. Vertebr. Paleontol. 2010, 30, 1059-1068.

49. Zammit, M.; Norris, R.M.; Kear, B.P. The Australian Cretaceous ichthyosaur Platypterygius australis: A description and review of postcranial remains. J. Vertebr. Paleontol. 2010, 30, 1726-1735.

50. Choo, B. Cretaceous ichthyosaurs from Western Australia. Rec. West. Aust. Mus. Suppl. 1999, 57, 207-218.

51. Kear, B.P. Biogeographic and biostratigraphic implications of Australian Mesozoic marine reptiles. Aust. Biologist 2004, 17, 4-22.

52. Lydekker, R. Catalogue of the fossil Reptilia and Amphibia in the British Museum (Natural History). Part II. Containing the Orders Ichthyopterygia and Sauropterygia; Trustees of the British Museum: London, UK, 1889; p. 307.

53. McGowan, C. Further evidence for the wide geographical distribution of ichthyosaur taxa (Reptilia: Ichthyosauria). J. Paleontol. 1978, 52, 1155-1162.

54. Spalletti, L.; Gasparini, Z.; Veiga, G.; Schwarts, E.; Fernández, M.; Matheos, S. Facies anóxicas, procesos deposicionales y herpetofauna de la rampa marina titoniano-berriasisana en la Cuenca Neuqina (Yesera del Tromen), Neuquén, Argentina. Rev. Geológ. Chile 1999, 26, 109-123, in Spanish.

55. Fischer, V.; Clément, A.; Guiomar, M.; Godefroit, P. The first definite record of a Valanginian ichthyosaur and its implications on the evolution of post-Liassic Ichthyosauria. Cretaceous Res. 2011, 32, 155-163.

56. Scheyer, T.M.; Moser, M. Survival of the thinnest: rediscovery of Bauer's (1898) ichthyosaur tooth sections from Upper Jurassic lithographic limestone quarries, south Germany. Swiss J. Geosci. 2011, 104, 147-157. 
57. Bardet, N.; Fernández, M. A new ichthyosaur from the upper Jurassic lithographic limestones of Bavaria. J. Paleontol. 2000, 74, 503-511.

58. Ensom, P.C.; Clements, R.G.; Feist-Brukhardt, S.; Milner, A.R.; Chitolie, J.; Jeffery, P.A.; Jones, C. The age and identity of an ichthyosaur reputedly from the Purbeck Limestone Group, Lower Cretaceous, Dorset, southern England. Cretaceous Res. 2009, 30, 699-709.

59. Massare, J.A. Tooth morphology and prey preference of Mesozoic marine reptiles. J. Vertebr. Paleontol. 1987, 7, 121-137.

60. Massare, J.A. Faunas, behavior, and evolution. In Ancient Marine Reptiles, 2nd ed.; Callaway, J.M., Nicholls, E.L., Eds.; Academic Press: San Diego, CA, USA, 1997; pp. 401-421.

61. Gilmore, C.W. Discovery of teeth in Baptanodon, an ichthyosaurian from the Jurassic of Wyoming. Science 1902, 16, 913-914.

62. Buchy, M.C. First record of Ophthalmosaurus (Reptilia: Ichthyosauria) from the Tithonian (Upper Jurassic) of Mexico. J. Paleontol. 2010, 84, 149-155.

63. Kirton, A.J. A Review of British Upper Jurassic Ichthyosaurs. Ph.D. Dissertation, University of Newcastle-upon-Tyne, Newcastle-upon-Tyne, Tyne; Wear, UK, 1981.

64. Fernández, M.S. A new ichthyosaur from the Tithonian (Late Jurassic) of the Neuquén Basin, Northwestern Patagonia, Argentina. J. Paleontol. 1997, 71, 479-484.

65. Fernández, M. Nuevo material de Caypullisaurus bonapartei Fernández (Reptilia: Ichthyosauridae) del Jurásico superior de la Cuenca Neuquina, Argentina. Ameghiniana 1998, 35, 21-24, in Spanish.

66. Kear, B.P. Cranial morphology of Platypterygius longmani Wade, 1990 (Reptilia: Ichthyosauria) from the Lower Cretaceous of Australia. Zool. J. Linn. Soc-Lond. 2005, 145, 583-622.

67. Kear, B.P.; Boles, W.E.; Smith, E.T. Unusual gut contents in a Cretaceous ichthyosaur. Proc. Roy. Soc. Lond. Biol. Lett. Suppl. 2003, 270, 206-208.

68. Kear, B.P.; Barrett, P. Reassessment of the English Cretaceous ichthyosaur Platypterygius campylodon. In Proceedings of Symposium of Vertebrate Palaeontology and Comparative Anatomy, Glasgow, UK, August-September 2007; p. 38.

69. Bennett, S.P.; Barrett, P.M.; Collinson, M.E.; Moore-Fay, S.; Davis, P.G.; Palmer, C.P. A new Specimen of Ichthyosaurus communis from Dorset, UK, and its bearing on the stratigraphical range of the species. P. Geologist. Assoc. 2012, 123, 146-154.

70. Lawrence, J.D. A Total Evidence Analysis of the Evolutionary History of the Thunnosaur Ichthyosaurs. M.Sc. Thesis, Graduate College of Bowling Green State University, Bowling Green, OH, USA, 2008.

71. Gasparini, Z.; Fernández, M. 1997. Tithonian marine reptiles of the eastern Pacific. In Ancient Marine Reptiles, 2nd Edition; Calloway, J.M., Nichols, E.L. Eds.; Academic Press: San Diego, CA, USA, 1997; pp. 223-253.

(C) 2012 by the authors; licensee MDPI, Basel, Switzerland. This article is an open access article distributed under the terms and conditions of the Creative Commons Attribution license (http://creativecommons.org/licenses/by/3.0/). 